\title{
Family Nursing as an Improvement Strategy of Family Health Index in Indonesia: A Literature Review
}

\author{
Andy Nuriyanto ${ }^{1}$ and Laili Rahayuwati ${ }^{2, *}$ \\ ${ }^{1}$ Community Nursing Department, Nursing Faculty of Padjadjaran University; nuriyantoandy@yahoo.co.id \\ 2 Community Nursing Department, Nursing Faculty of Padjadjaran University; lailira2002@yahoo.com \\ * Correspondence: nuriyantoandy@yahoo.co.id; Tel.: +6281347544054
}

Literature Review

Received: August 5, 2019; Accepted: September 15, 2019 ; Published: October 15, 2019

https://doi.org/10.29253/achnr.2019.1721

\begin{abstract}
The occurrence of health issues in the family affected by the ability of the family itself to carry out the role and task of family health care. Family nursing has been developed in various countries as a solution to solve individual, family, and community health issues in a region. The family health status in Indonesia is measured by the Family Health Index (FHI) value, comprising the category of unhealthy families (FHI < 0.50), pre-healthy families (FHI value of 0.50 to 0.80 ), and healthy families (FHI > 0.8). This study aims to generate a literature review on strategies that can be used to improve the Family Health Index. The search database includes CINAHL, MEDLINE, and Google Scholar with several keywords: 'family nursing', 'family health', and 'family health status'. 102 articles published between the year of 2000 until 2019 have been obtained. The results of the literature review indicate that family nursing is an innovative and efficient strategy to achieve a preferable health status as well as a better quality of human life. Family nursing has a positive correlation with the increased ability of families to carry out their task in maintaining, preventing and overcoming family health issues independently. Research on the families' ability to carry out health care tasks to improve the health status by measuring FHI has never been done previously. Future research is required to discuss the relationship of families' ability in carrying out the five health care tasks to improve FHI independently in Indonesia.
\end{abstract}

Keywords: family health nursing; family health index; family health status

\section{Introduction}

The increase in population, economic needs, technological advancements, as well as requirements and changes in health services have encouraged governments in several developed and developing countries to find cost-effective innovations for family-based health care throughout the world. Curative health service delivery in the current health service unit is not sufficient to meet future health demands. As a result, WHO in Europe has recommended a family-oriented health program since the period of 1998 through the provision of family health nurses. Through such family nursing, multidimensional activities are carried out not only for individuals but also for families, groups and populations. Family nursing innovation activities aim to promote health, protect humans throughout life, and proactively prevent disease and disability to maintain the health status of individuals in the family and community structure (Obbia, 2014).

Copyright(C) 2019 by the authors. Submitted for open access publication under the terms and conditions of the Creative Commons Attribution (CC BY) license. 
Family-oriented nursing is the right solution to solve health problems. Family nursing in Europe began to be applied in several developed and developing countries by maximizing promotive and preventive efforts through family empowerment. The family nursing program is a unified intact between the family and the nurse in order to establish relationships through the ideal communication principles in achieving family health status (Dorell, Östlund, \& Sundin, 2016). Family nursing is also applied in several states in America as an effective solution to health problems. The goal is for families to be involved as partners in planning, service and system development, enhancing nursing effectiveness research and providing policy feedback on family health nursing practice (Spencer, Blau, \& Mallery, 2010).

Through family nursing, the existence of family becomes highly crucial in managing the incidence of the disease and maintain its health status. This is because every family health problem can affect the role of other family members (Effendy, 1998). The family nursing approach can also be applied in efforts to solve health problems at the community level (Dorell et al., 2016). This is in line with the main target of the implemented health program, which is the family itself. Family is the smallest organizational unit of society consisting of heads and family members who gather and live under one roof and have interdependence to one another (Kemenkumham, 2009). In addition, the family also has an important role as a provider of human resources, material, financial and social objectives, and health care for family members (Irinoye, Ogunfowokan, \& Olaogun, 2006). As a result, it can be concluded that, where families with good health status are gathered in a community, they can support the development of a community with good health status.

Family nursing is also a prominent part of the community health care program (known as Perkesmas) in first-level health facilities, particularly with the existence of Healthy Indonesia Program through Family Approach (Program Indonesia Sehat dengan Pendekatan Keluarga, abbreviated as: PISPK). PIS-PK is an innovation in the health sector which is on the agenda of the National Long-Term Development Plan in the health sector for the period between 2005 and 2025 in order to realize a better quality of life for Indonesian people. The objective of the integrated family nursing program in PIS-PK is to improve the ability of families to carry out their tasks to solve health problems they face independently (Siti, Nursalam, Adriani, Ahsan, \& Tantut, 2018). Hence, with the existence of PIS-PK, it is expected that families can face and solve family health problems independently by empowering the ability of the family.

The ability of families to carry out family care duties independently in solving health problems is an important factor in achieving family health status. The task of family care consists of five main interconnected tasks, namely: 1) recognizing health problems, 2) deciding on health measures, 3) conducting the nursing process, 4) modifying the environment, and 5) accessing health facilities (Ratnawati, 2018). The ability of the family to carry out the five family tasks illustrates the role and function of the family in health care through coaching and mentoring by nurses (Agrina \& Zulfitri, 2013). By carrying out family coaching and mentoring in health care units as well as through home visits, it is expected that families can be more cooperative and are capable to prevent and overcome health problems faced independently (Siti et al., 2018). Therefore, with coaching and mentoring in health care, families can improve their abilities independently to maintain, overcome and prevent family health problems.

The process of achieving family health status through the PIS-PK program carried out at each community health center begins with planning and preparation in each working area. The ultimate goal of this program is to collect family health data based on 12 indicators of family health. The data collection and implementation of the program is carried out by competent health workers and can carry out activities in accordance with the technical guidelines with the output data in the form of a Family Health Index as a description of the family's health status. Family Health Index is divided into three levels, namely: 1) Family Health Index value of $<50.00 \%=$ unhealthy, 2) Family Health Index value of 50.00\% to $80.00 \%=$ pre-healthy, and 3) Family Health Index value of $>80 \%=$ healthy (Kemenkes, 2016a). Family Health Index can also be used in the assessment of health indices at the tier level starting from the family level, community level (Sub-district, District, Regional level), up to the national level to describe the Indonesian Health Index.

As what has been explained in the background of the study, it is necessary to conduct a literature review on family nursing strategies to improve health status that can be applied according to the situation in Indonesia. This literature review aims to identify the implementation of family nursing 
systems to maintain, improve health status, and resolve health problems that occur in families independently with a Family Health Index assessment

\section{Methods}

The literature review method has been used in the research. Search for supporting articles is conducted through the CINAHL, MEDLINE, and Google Scholar databases. This literature review uses keywords in Indonesian and English language (bilingual). In Indonesian language, the keywords used are: 'pendekatan keluarga', 'keperawatan keluarga', and 'kesehatan keluarga'. Whereas in English language, the keywords used are: 'family health approach', 'family nursing', and 'family health'. There is a total of 102 suitable articles found using these keywords with a total synthesis of 9 articles published from the period between 2000 and 2019. The articles are then evaluated according to criteria regarding the nursing concept implementation with a family approach to achieve family health status and then a review is conducted. Moreover, government theory and policy are also used in this literature review to analyze these papers comparatively and to strengthen the reasons for the literature being studied.

\section{Results (or Results and Discussion)}

Nine articles were synthesized for analysis with the main orientation of family nursing on general family health problems. Research that has been conducted qualitatively and quantitatively in the realm of education and practice of family health nursing with the orientation of the role of nursing staff in realizing good family nursing care along with the impact on families who obtain the intervention.

Table 1: Family Nursing Implementation to Improve Family Health Status

\begin{tabular}{l} 
Author and Research Title \\
\hline Murray (2004) \\
"Family Health Nursing: the education \\
programme for the WHO European Scottish \\
Pilot"
\end{tabular}

Family nursing program is a solution for families to overcome health problems they deal with. Family nurses must carry out their roles and functions in accordance with the education curriculum in collaboration with other community health care teams. The most prominent role of a nurse in family nursing is to establish a propitious communication with the family.

Irinoye et al. (2006)

"Family Nursing Education and Family Nursing Practice in Nigeria"
Parfitt and Cornish (2007)

"Implementing Family Health Nursing in Tajikistan: From policy to practice in primary health care reform"
Graduate nursing education curriculum in Nigeria shows that nurses with master and doctoral degrees as well as community nursing specialist degrees already have basic theories about family nursing. However, many nurses in Nigeria with such degree are not directly involved in clinical practice of family nursing. They put more effort in the direction of developing specialization and view that nursing with family orientation has a further scope than public health nursing.

Nurses were initially considered inferior to doctors. In this research, family nurses were considered to have greater clinical responsibility than doctors because nurses have a direct communication with families by taking the responsibility for disease prevention and treatment, making independent decisions and working with a team of doctors and all family members they cared for.

The main inhibiting factor for family nurses is the friction in the differences of nurses' salaries and other health workers, so that the success of family health care is not met due to an uneven financing system. In other words, the 


\section{Author and Research Title}

Spencer et al. (2010)

"Family-Driven Care in America: More Than a Good Idea"

Häggman-Laitila, Tanninen, and Pietilä (2010)

"Effectiveness of resource-enhancing family-oriented intervention"

Agrina and Zulfitri (2013)

"Efektifitas Asuhan Keperawatan Keluarga

Terhadap Tingkat Kemandirian Keluarga

Mengatasi Masalah Kesehatan di Keluarga"

Obbia (2014)

"Introducing the family health nurse in Italy"

Marwati, Aisya, and Alifariani (2018) "Promkes untuk Mendukung PIS-PK Indikator Hipertensi dan KB di Desa Combongan"

Siti et al. (2018)

"Structural Model for Public Health Nurses' Performance in the Implementation of Family Nursing Based on Nursing Relational Capital"

\section{Conclusions}

issue of nurse salaries caused serious problems for nurses as health workers, this was due to the cultural heritage of the former colony of the Soviet Union.

The critical success factor for this family nursing program is the enthusiasm of the nurse itself and the acceptance of the presence of the nurse by the service user.

Nurses as implementers of family nursing are expected to facilitate the ability of families as partners in planning, developing services and care systems, implementing and improving care research, and feedback on nursing policies and practices.

Empirical knowledge about nurses' performance on family nursing is still minimal related to methods, reciprocal relationships, and increased family resources that can affect family health status. Family nurses are needed to support the family in: 1) improving the role of parents, 2) strengthening family social relationships, and 3) increasing family resources to manage family tasks towards family members, especially children.

There is a significant effect in providing family nursing care to the level of family independence overcoming health problems ( $\mathrm{p}$ value $=0.00$ ).

WHO-EU recommended Family Health Nursing program with the target of palliative care services, case management, family nurse partnerships, nursing clinics, community nursing, home visits, etc. The need for recognition of Family Health Nursing as an integrated form of nursing.

The goal of Healthy Indonesia Program through Family Approach is to improve health status through health efforts and community empowerment with a family approach.

Factors that affect the Performance of Nurses and Family Independence include 1) structural capital of nursing, 2) human resources of nursing, 3) client factors, 4) family factors, 5) factors of nursing relationships.

An ideal nurse performance in family nursing care can increase family independence in caring for sick family members.

In the curriculum of nursing education in Europe, the family nursing program requires the role of every nurse to provide solutions in solving family health problems. Nurses must be able to carry out their roles and functions in accordance with the educational curriculum that they have taken and work with other community health care teams. The most important role of nurses in family nursing is to establish good communication with the target performance to improve the health status of the family 
(Murray, 2004). Nurses with master and doctoral academic degrees or community nursing specialists are considered to have strong basic theories about family nursing, but many nurses in Nigeria with these degrees are not directly involved in the clinical practice of family nursing. They put more effort in the direction of developing specialization and view that nursing with family orientation has a further scope than public health nursing (Irinoye et al., 2006).

Qualitative research conducted by Häggman-Laitila et al. (2010) explained that empirical knowledge about nurses' performance on family nursing is still limited when it comes to methods, reciprocal relationships, and increased family resources that can affect family health status. The results of the study stated that the presence of nurses is needed to support families in: 1) improving the role of parents, 2) strengthening family social relationships, and 3) increasing family resources to manage family tasks towards family members, especially to children. In addition, research conducted by Agrina and Zulfitri (2013) stated that there is a significant effect on the provision of family nursing care to increase the level of family independence to overcome the health problems experienced. This study concluded that the level of family independence increased after good family nursing care was carried out in accordance with the prescribed instructions.

The level of family independence can be achieved well, and this can be clearly seen from the ability of families to understand and carry out five family health care tasks. The ability to understand and carry out these tasks is highly dependent on the role of nurses in providing nursing care. As explained in the results of a previous study conducted by Agrina and Zulfitri (2013), the one-group pretest-posttest design resulted in a p-value of 0,000 which concluded that family nursing care can increase family independence to overcome health problems. In implementing the intended family nursing program, the family is expected to get coaching and mentoring efforts to carry out five family health care tasks by nurses in solving health problems experienced by the family independently Agrina and Zulfitri (2013).

In Italy, family nursing is also a program recommended by WHO-Europe with the target of palliative care, case management, family nurse partnerships, nursing clinics, community nursing, home visits, etc. which are directly carried out by nurses (Obbia, 2014). The implementation of this program requires nurses to be more active in managing their target families. Although nurses were initially considered inferior to doctors, in a study conducted by Parfitt and Cornish (2007), nurses had greater clinical responsibility than doctors. This is because nurses make direct contact with the family and take full responsibility for disease prevention and treatment, make independent decisions, and work closely with the team of doctors and family members as a whole. Hence, doctors may assess and assume that nurses have a direct positive impact on improving health in the family (Obbia, 2014).

Inhibiting and supporting factors of the implementation of family nursing programs need to be known and acted upon by each policymaker in a country. The most important inhibiting factor for family nurses in carrying out family nursing, as stated on a research conducted by Parfitt and Cornish (2007) in Tajikistan, is the difference in salary of nurses with other health workers. This is considered to make the success of the family care program being unachieved properly due to an uneven operational financing system. The issue of nurses' salaries has become a serious issue as a health worker, which is a contributing factor to the culture of having a negative view of nurses as a legacy for the former colony of the Soviet Union. Thus, supporting factors for the success of family nursing are the enthusiasm of the nurse itself and the existence of the nurse in the eyes of users of nursing services as interconnected subjects during the family care process.

The interrelationship of the mutual relationship between nurses and family is a factor that can be developed to support the success of the family nursing program. In family nursing research entitled "Family-Driven Care in America: More Than a Good Idea" suggests that the ability of family's needs to be developed as partners in planning, developing care services and systems, implementing and improving care research, and nursing policy and practice feedback (Spencer et al., 2010). As such, the reciprocal relationship between nurses and family can be used as a support to strengthen the family's view of the policy from the point of view of the family itself as well as the government's point of view regarding family nursing that is carried out to realize better health status.

In accordance with Law 36 of 2009 concerning Health Chapter II article 3 states that the purpose of health development is to increase awareness, willingness and ability to live healthy for everyone in order to realize the highest degree of public health (SekretarisNegara, 2009). Achieving health status, as stated on the research by (Marwati et al., 2018) concerning public health, states that the goal of Healthy 
Indonesia Program through Family Approach is to increase health status through health efforts and community empowerment with family orientation. Community health centers are at the forefront of determining the success of this program in each of its working areas. Efforts that can be maximized are promotive efforts through health education to the community to strengthen the realization of health development (Marwati et al., 2018). Practically in the 2018 Health Profile of Indonesia, it is stated that the Human Development Index (HDI) increased 4.86 points, from 66.53 in 2010 to 71.39 in 2018. However, when observing the Family Health Index data that can be accessed through the keluargasehat.kemkes.go.id website, states that the national Family Health Index is still in the value of 0.18 or in an unhealthy range. The lowest Family Health Index value is on the seventh indicator, namely hypertension patients undergoing regular treatment at $24.39 \%$ of the national target (Kemenkes, 2019).

\section{Discussion}

The concept of family nursing emerged from the World Health Organization's initiative to develop health practitioners' competencies with family goals as the focus of organizing practices (WHO, 2000). The main object of family nursing is the family itself and is in line with Healthy Indonesia Program through Family Approach to improve the ability of families to carry out family care duties in order to create good health status (Kemenkes, 2017a). The principle of the family approach to Healthy Indonesia Program through Family Approach is also in line with the curriculum of family nursing education to encourage nurses to act as providers of nursing services, case decision makers, communicators, and managers (Murray, 2004). This is supported by nurses being able to carry out their roles at each stage of Healthy Indonesia Program through Family Approach activities as managers for work goals and other teams when preparing activities, caregiver providers and case finding during data collection and intervention, and communicators and educator (liaison and education provider) at the time of the followup activities (Virdasari, Arso, \& Fatmasari, 2018).

Healthy Indonesia Program through Family Approach encourages families to be able to improve and maintain their health status independently. Improving family health status is conducted through the implementation of family care tasks by increasing: 1) the ability of families to recognize problems, 2) the ability of families to make decisions, 3) the ability of families to take care of one another, 4) the ability of families to modify the environment, and 5) the ability of families to access health facilities (Parellangi, 2018). Through these five family health care tasks, family independence to solve problems and create good health status can be improved by implementing family nursing care (Agrina \& Zulfitri, 2013). This shows that the better implementation of family nursing care has positive implications for increasing family independence to solve problems and maintain their health status independently.

In accordance with the mandate set out in Law Number 23 of 2014 concerning Regional Government which is also in line with the Law 36 of 2009 concerning Health, it is stated that family development is an effort in order to create a family that has a quality of life in a healthy environment (SekretarisNegara, 2014). These efforts can be maximized by empowering through the implementation of the family health nursing function. There are five family functions (the health care function), especially in the maintenance or family health nursing function. The function of the family aims to maintain the state of health in all family members so as to have high productivity on an ongoing basis. The intended family health function is developed into a family task in the health field (Friedman, Bowden, \& Jones, 2010) with the participation of each family member to maintain health conditions in the family.

The role of families in achieving optimal family care tasks is a comprehensive and independent solution to family health problems (Murray, 2004). This shows that the relationship between nurses and family members with each other is highly influential in every health problem they deal with. In carrying out family care tasks, a comprehensive nursing model with a family-oriented curriculum is needed (Irinoye et al., 2006). It aims to create positive reciprocity as a strength for nurses to create family health status and the existence of family nursing as an effort to create a better family health status.

In addition to the role of the family as the main support to achieve good health status, the role of the nurse is also needed to facilitate the role of the family. The role of nurses as providers of nursing services carried out by a nurse, especially in the assessment and examination of the history of the disease that can occur in cases of maternal and child health, hypertension (measurement of blood pressure), tuberculosis, mental disorders, and a history of smokers in the family. The role of nurses as communicators and educators and community leaders in data collection activities is to conduct counseling, health education, 
and provide positive feedback when health problems are found in accordance with the indicators assessed. The role of decision-makers and case finding for nurses is that nurses can determine the assessment of a healthy family index and provide suggestions and solutions related to family health problems using the family education information package (referred to as Pinkesga) (Kemenkes, 2016c).

In addition to this role, nurses also have the ability and the amount of human resources that can be relied upon in activities to improve health status with orientation to the family. For example, as an implementer of Healthy Indonesia Program through Family Approach, nurses can collect data, manage data, analyze data, formulate interventions, carry out interventions by conducting nursing services, and make reports on community health center information systems (Kemenkes, 2016c). In addition, the composition of nurses is the most dominant health worker in First-Level Health Facilities throughout Indonesia, amounting to $49 \%$ of the total 1,000,780 health workers (Kemenkes, 2017b). This illustrates that nurses become an important part in successfully improving health status with a family approach.

The family approach in realizing a Healthy Indonesia must be absolutely accompanied by family and community empowerment in health development (Kemenkes, 2016a). This is evidenced by the positive change in Basic Health Research data since 2013. Data showed the proportion of stunting babies born (body length $<48 \mathrm{~cm}$ ) at $20.2 \%$ in the period, and data also reveal that $37.2 \%$ of toddler groups is also suffering from stunting. To cope with stunting, detection and health intervention must be done as early as possible by monitoring the growth of infants and toddlers through weighing at the Integrated Service Post (referred to as Posyandu) regularly. In 2007, the proportion of children under five visiting the Integrated Service Post in the last six months was only 25.5\% and increased in 2013 to 34.3\% (Riskesdas, 2013). If growth monitoring is an important matter to do for infants and toddlers in the Integrated Service Post, then infants and toddlers who do not come should have a home visit to follow up on the problems found. Coming to the Integrated Service Post or home visits in such cases requires good collaboration between health workers, health leaders and families. This shows that the family approach and community empowerment is an absolute thing to do in realizing the prevention of stunting as a health problem in the family.

In addition, family health monitoring can also be done on families with non-communicable diseases such as hypertension. It is known that the prevalence of hypertension in 2013 was $25.8 \%$ or a total of 42.1 million people. Of this amount, only $36.8 \%$ of hypertension sufferers made contact with health workers, the remaining approximately $2 / 3$ of hypertension cases did not realize that they were suffering from hypertension (Riskesdas, 2013). The data shows that if there is no family approach by home visit, $2 / 3$ or 28 million people with hypertension may never be monitored and handled. Coming to Integrated Development Post (referred to as Posbindu) or community health centers or home visits in such cases also requires good coordination between health workers, health leaders and families. It also reinforces that an absolute family approach controls non-communicable diseases.

Based on the Family Health Index data that can be accessed through keluargasehat.kemkes.go.id website, it is known that the national IKS is 0.18 or in the unhealthy range (Kemenkes, 2019). This illustrates that the health program with a family approach in Indonesia has not been implemented well. When viewed from the perspective of family nursing, the current family approach strategy does not maximize the role of the nurse. Therefore, health advocacy during data collection and role as case finding, and communicator and educator are not conducted properly because the data collection is not from the nursing profession. Supposedly after the data collection, problems and health plans have been recorded and the family has the motivation to improve the ability to overcome problems independently. In addition, a resurvey of Family Health Index is rarely conducted to reassess its changes and to improve family data in the work area of each health centers.

An indicator of hypertension patients undergoing regular treatment which is also still low at $24.39 \%$ of the national target (Kemenkes, 2019), also gives meaning that the family approach is not going well. Health workers should conduct home visits to monitor families with hypertension health problems. However, because data collection is not carried out by competent health workers, blood pressure is usually obtained through interview information without measurement. Therefore, the follow-up of the Community Health Nursing Services program was also not carried out properly due to incomplete information. This is the main point that family nursing is a strategy that can be implemented in Indonesia. Considering the family nursing curriculum and the dominance of the number of nurses in Indonesia of 
$49 \%$ of the total $1,000,780$ health workers (Kemenkes, 2017b), nurses are very likely to be the main implementers and pilot projects of the Family Health Index improvement strategy in Indonesia.

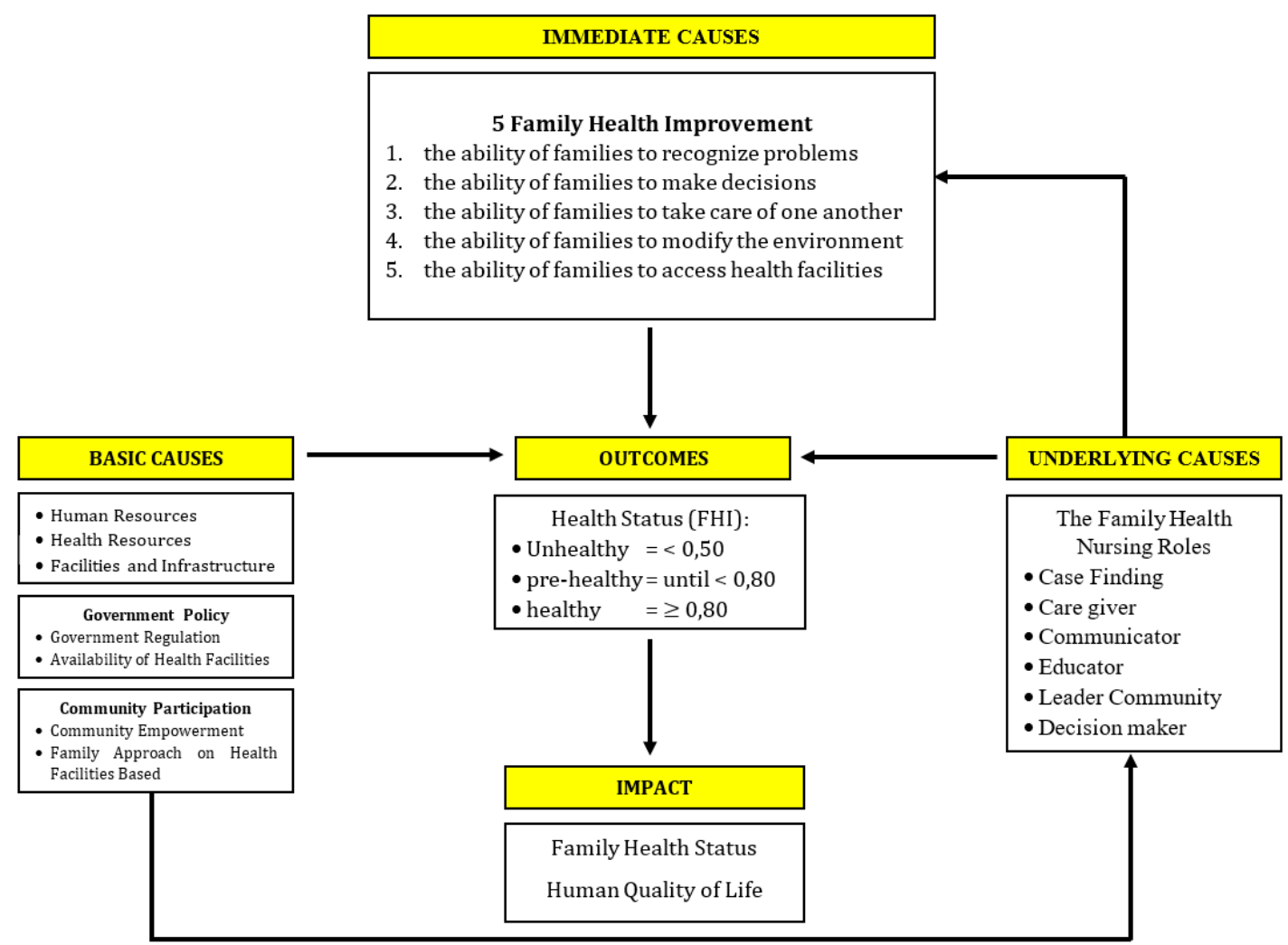

Diagram 1: The flow of nursing implementation to improve health status with a family approach

Diagram 1 above discussing the flow of nursing implementation to improve health status with a family approach is a general description of nursing strategies to improve Family Health Index in Indonesia. The government has an important role to provide human resources, health resources and infrastructure which are the main capital to realize health status and better quality of human life. In addition, there is a need for government policy support in the academic and clinical spheres as well as community empowerment as a regulatory basis for realizing the program. Thus, the inhibiting factors of nurses in family nursing related to differences in nurse salaries or operational financing which are the main issues, may not occur. This can increase the enthusiasm of nurses to increase their presence in the eyes of users of nursing services so that it will increase supporting factors to achieve the ultimate goal of family nursing (Parfitt \& Cornish, 2007).

As a form of implementing health services to improve the ability of family care independently, nurses must carry out their role with the aim of maximizing five family care tasks. The roles of nurses in question include being a case finder, nursing service provider, communicator, health information provider, group planner/coordinator, and decision-maker. This role aims to provide positive changes to the independence of the family in carrying out five family care tasks as a determinant of family health status that can be assessed with Family Health Index. So that the final goal in the form of good family health status can be achieved independently.

As what has been explained on the review of the scientific articles, it was concluded that to achieve good family health status five elements are needed. The five elements are: 1) human resources as targets, 2) health workforce resources as implementers, 3) facilities and infrastructure as supporters, 4) government policies as regulations, and 5) family/community participation in health services. The five main points become the basis of the role of nurses in a dependent, independent and interdependent manner that has a direct impact on the independence of the family carrying out five family care tasks to achieve health status independently by Family Health Index assessment. A good Family Health Index 
score is directly expected to have a positive impact on family health status and the quality of human life (Diagram 1).

As a strategy to improve Family Health Index, family nursing must place a position in every supporting element of the family health status. The first element is human resources/health workers as the target and program implementers in accordance with the concept of nursing, namely the target family by maximizing the role of the family nurse. Second, the facilities and infrastructure as program proponent that can be fulfilled through the evaluation element of community health center accreditation by meeting the service standards and infrastructure available at the community health center (Kemenkes, 2014). The fourth element is the government policy which is the basis of implementing a program to improve family health status, namely the existence of regulations on nursing and the Healthy Indonesia Program with a Family Approach (Kemenkes, 2016b). The fifth element is a form of community and family empowerment based on the Indonesian mutual cooperation culture and empowerment programs that can be maximized through the function of the community health center. Therefore, it can be concluded that family nursing has the potential to be applied as a strategy to increase Family Health Index in Indonesia

\section{Conclusions and Suggestions}

Based on the literature review that has been carried out, it can be concluded that family nursing is a form of a social approach which observes family as a unit that provides mutual reciprocity between nurses and all family members to achieve optimal family health status. The implementation of family nursing by carrying out the role of nurse has positive implications for increasing the independence of the family in achieving its health status. Family nursing can be used as a strategy to increase Family Health Index in Indonesia. However, in relation to the literature review, no qualitative or quantitative articles has been found regarding the direct relationship or effect of the family's ability to carry out five family care tasks to Family Health Index as a description of the family's health status.

\section{References}

Agrina, A., \& Zulfitri, R. (2013). Efektifitas Asuhan Keperawatan Keluarga terhadap Tingkat Kemandirian Keluarga Mengatasi Masalah Kesehatan Di Keluarga. Sorot, 7(2), 81-89.

Dorell, Å., Östlund, U., \& Sundin, K. (2016). Nurses' perspective of conducting family conversation. International journal of qualitative studies on health and well-being, 11(1), 30867.

Effendy, N. (1998). Dasar-dasar keperawatan kesehatan masyarakat.

Friedman, M. M., Bowden, V. R., \& Jones, E. (2010). Buku Ajar Keperawatan Keluarga. Riset, Teori, dan Praktik. Jakarta: EGC.

Häggman-Laitila, A., Tanninen, H. M., \& Pietilä, A. M. (2010). Effectiveness of resource-enhancing familyoriented intervention. Journal of Clinical Nursing, 19(17-18), 2500-2510.

Irinoye, O., Ogunfowokan, A., \& Olaogun, A. (2006). Family nursing education and family nursing practice in Nigeria. Journal of Family Nursing, 12(4), 442-447.

Kemenkes. (2014). Permenkes Nomor 75 Tahun 2014 tentang Pusat Kesehatan Masyarakat. Jakarta

Kemenkes. (2016a). Pedoman Umum Program Indonesia Sehat dengan Pendekatan Keluarga. In.

Kemenkes. (2016b). Permenkes 39 Tahun 2016 tentang PIS-PK. Jakarta: Kemenkes RI

Kemenkes. (2016c). Permenkes Nomor 44 tahun 2016 tentang Pedoman Manajemen Puskesmas. Jakarta: Kemenkes RI Retrieved from http://www.kesga.kemkes.go.id/images/pedoman/PMK_No._44_ttg_Pedoman_Manajemen_Pu skesmas_\%20(1).pdf

Kemenkes. (2017a). Petunjuk Teknis Penguatan Manajemen Puskesmas Dengan Pendekatan Keluarga Edisi-2. In. Jakarta: Kemenkes RI.

Kemenkes. (2017b). Situasi Tenaga Keperawatan Indonesia. In: InfoDatin.

Kemenkes. (2019). Dashboard Indikator Keluarga Sehat. Retrieved from http://dashboardkeluargasehat.kemkes.go.id/

Kemenkumham. (2009). Undang-Undang Republik Indonesia Nomor 52 Tahun 2019 Tentang Perkembangan Kependudukan dan Pembangunan Keluarga. Jakarta

Marwati, T., Aisya, I. R., \& Alifariani, A. (2018). Promosi Kesehatan Untuk Mendukung Program Sehat Dengan Pendekatan Keluarga (PIS-PK) Indikator Hipertensi dan KB di Desa Combongan. Jurnal Pemberdayaan : Publikasi Hasil Pengabdian Kepada Masyarakat, 2(1), 75-82. 
Murray, I. (2004). Family health nursing: the education programme for the WHO Europe Scottish Pilot. British journal of community nursing, 9(6), 245-250.

Obbia, P. (2014). Introducing the family health nurse in Italy. International Journal of Integrated Care(6). Parellangi, A. (2018). Home Care Nursing Aplikasi Praktik Berbasis Evidence Based.

Parfitt, B. A., \& Cornish, F. (2007). Implementing family health nursing in Tajikistan: from policy to practice in primary health care reform. Social Science \& Medicine, 65(8), 1720-1729.

Ratnawati, E. (2018). Keperawatan Komunitas (Vol. 1). Yogyakarta: Pustaka Baru Press.

Riskesdas. (2013). Riskesdas 2013. Jakarta: Badan Litbang Kesehatan.

SekretarisNegara. (2009). Undang-undang Nomor 36 Tahun 2009 Tentang Kesehatan. Jakarta: Sekretaris Negara RI

SekretarisNegara. (2014). Undang-undang Nomor 23 tahun 2014 Tentang Pemerintah Daerah. Jakarta: Sekretaris Negara RI

Siti, N. K., Nursalam, N., Adriani, M., Ahsan, A., \& Tantut, S. (2018). Structural Model for Public Health Nurses' Performance in the Implementation of Family Nursing Based on Nursing Relational Capital. International Journal of Caring Sciences, 11(2), 1-13.

Spencer, S. A., Blau, G. M., \& Mallery, C. J. (2010). Family-driven care in America: More than a good idea. Journal of the Canadian Academy of Child and Adolescent Psychiatry, 19(3), 176.

Virdasari, E., Arso, S. P., \& Fatmasari, E. Y. (2018). Analisis Kegiatan Pendataan Keluarga Program Indonesia Sehat Dengan Pendekatan Keluarga di Puskesmas Kota Semarang (Studi Kasus pada Puskesmas Mijen). Jurnal Kesehatan Masyarakat (e-Journal), 6(5), 52-64.

WHO. (2000). The family health nurse context. Conceptual framework and curriculum. WHO, Kopenhagen. 